\title{
Accessibility of Disabled-Friendly Public Services: A Case Study in Bantul District Police
}

\author{
Atik Septi Winarsih $^{1, *}$ Dewi Sekar Kencono ${ }^{2}$ Muhammad Iqbal $^{3}$ \\ ${ }^{1}$ Department of Government Affairs and Administration Universitas Muhammadiyah Yogyakarta, Indonesia \\ ${ }^{2}$ Department of Government Affairs and Administration Universitas Muhammadiyah Yogyakarta, Indonesia \\ Doctoral of Public Administration, Departement of Public Policy and Management, Universitas Gadjah Mada, \\ ${ }^{3}$ Department of Political Science National Cheng Kung University of Taiwan \\ *Email: atikseptiwinarsih@umy.ac.id
}

\begin{abstract}
In 2018, the minister Reform and Bureaucratic were giving the award to the 61 heads of regions with the best public service. This award is intended to provide an evaluation of public services to the community. The results of the evaluation of services public in 2018 are as much as 16 units of the organizers of the service received category A (excellent service category). This has experienced a surge in winning the top service category, compared to last year 's new one, namely AM Parikesit Regional Hospital, Kutai Kartanegara Regency. The increase also occurred in the unit servicing the public by category A- (very good), which in the year 2017 a new 50, tahun2018 into 86 units (Ministry for Administrative Reform State and Reform Bureaucracy, November 27, 2018). Based on the results of the assessment are then in the research is that it will be one of its aspects is a means of infrastructure in Bantul Regency. Associated with means of infrastructure is then expected to serve the public are given can be accessed by all parties, including among others are people with disabilities or persons with disabilities. If the means of infrastructure that is given by the organizers of the service of public good and friendly with disabilities it is not going to no more extended care that discriminatory that only can be accessed by residents usual. Talking about people with disabilities is indeed very interesting for people with disabilities is more like using the term ' disability ' and ' disabled ' (different ability, differently-abled people) than the term ' disability ' and ' persons with disabilities ' which tends to connote negative it. Disability is the person who has the ability that differs from humans more. Because different, disabilities need facilities that differ from the usual. Needs to be adjusted and added services for people with disabilities. But that does not mean because they are different; we ordinary people have the right to humiliate, exclude, or discriminate against them. The findings in this study are the existence of facilities or lack of infrastructure that supports people with disabilities to feel comfortable using, for example, access roads that are made in tiers (stairs) are difficult for people with disabilities who use wheelchairs. Besides, toilet facilities are less supportive because usually only a squat bathroom is provided.
\end{abstract}

Keywords: Accessibility, Public Service, Disabled

\section{BACKGROUND}

In the modern era, the level of mobility is getting faster and more advanced; this is also felt by persons with disabilities among the surrounding community. However, it is also not uncommon for persons with disabilities to receive or experience discrimination. Discrimination experienced by persons with disabilities, either directly or indirectly, has made people aware that they are human just like others and equal in rights and freedom in making choices. Discrimination against persons with disabilities is often seen in several areas of society or public places; the community still considers that people with disabilities are still not good at anything, except for the service for making Driving Licenses (SIM) [1].

Based on Law No. 8 of 2016, persons with disabilities state that persons with disabilities are entitled to social welfare space, rights and obligations, employment, free from stigma, privacy, justice, entrepreneurship and cooperatives, health, politics, 
religion, sports, culture and tourism, accessibility, public space, public services [2]. So services for people with disabilities need to be fulfilled again to be carried out correctly and adequately. The importance of special facilities or services for persons with disabilities who still find it challenging to carry out activities in public spaces that are already available due to the lack of awareness of the surrounding community who do not treat them well or adequately, and also the lack of attention from local service providers for people with disabilities ([3]; [4]).

In 2019 , the number of people with disabilities in Bantul Regency reached 1,847. This affects the services of several facilities, including the manufacture of SIM. Procedures that must be fulfilled to obtain a driving license (SIM) such as first registration, then filling out forms and taking tests both in writing and direct practice using a vehicle with a traffic simulation provided on the spot, these requirements can be met by non-disabled and disabilities. For persons with disabilities, there are several different procedures for non-disabled people depending on the type of disability. If persons with disabilities have met these requirements, they will get a special disability SIM, namely SIM D [5].

One of the cases found by researchers that the implementation of SIM D has not been fully achieved for persons with disabilities [6]. The following is the data based on the Bantul Police from 2015 to 2018. Registration for SIM D is still relatively small, but only eighteen people [7]. The application of SIM D has only started since 2015, previously people with disabilities were still joining SIM A and SIM C together with other people adjusting the vehicle used. Persons with disabilities who already have a SIM before the start of SIM D implementation can only renew it in 2020 because the SIM validity period is only five years [8]. SIM services at the Bantul Police are already reasonably good in terms of special SIM services for disabilities and have been implemented since 2015, compared to other cities/districts in Special Region of Yogyakarta (DIY).

One of the improvements in services for people with disabilities is an increase in special driving license (SIM) services for disabilities that need to be paid attention and strengthened by the Yogyakarta Regional Regulation No. 4 of 2012 which regulates rights and fulfilment of persons with disabilities in DIY, especially those in Bantul SIM D's service. This regional regulation is the only one in Indonesia that must be supported to provide good SIM services to persons with disabilities equally.

\section{LITERATURE REVIEW}

Traditionally, the definition of accessibility to public services has been extended to the ability of everyone to access - meaning use and/or to interact with - a product or service, regardless of their physical, economic or cultural situation [9]. Accessibility can be understood as the extent to which as many people can access an interactive product as possible. The United Nations (UN), in the Convention on the Rights of Persons with Disabilities (CRPD), recognizes the fundamental role of government in promoting accessibility and provides a more political perspective in which States Parties shall take appropriate steps to ensure access for persons with disabilities basic equivalents to others, to the physical environment, transportation, information and communication, including information and communication technology and systems, and to other facilities and services open to or made available to the public, both in urban and rural areas [16]. These measures, which should include the identification and removal of barriers and barriers to accessibility, apply to [18]:

a. Buildings, roads, transportation and other indoor and outdoor facilities, including schools, housing, medical facilities, and workplaces;

b. Information, communications and other services, including electronic services and emergency services.

Although the idea of accessibility is connected to the idea of usability, usage refers to the degree to which a user can achieve his goals by using the product, efficiency, accessibility is a measure of whether a person can interact, access information, or do something else - and not how well he can do it; refers to the inclusion or exclusion of people from using the product [15]. [17] mentions several reasons that alienate people from inaccessible interactive products:

a. Physical: someone does not have the power to operate controls or cannot read instructions; conceptual: someone does not understand user instructions or has a different mental model;

b. Economical: one cannot afford a product;

c. Culture: one does not understand the metaphors used as the basis for product interactions;

d. Social: a person is not part of a social group with whom he can interact or does not understand social conventions once in a group.

The theoretical conceptualization for accessibility can be enlarged to expand the term: Universal Access (UA). According to [19], UA has accessibility and usability as two main requirements but adds and emphasizes social and political elements. UA introduces a new and challenging dimension: human diversity. In other words, UA provides theoretical, methodological, and empirical research to address accessibility and usability issues, and technology acceptance to anyone, anywhere, anytime, and in any media and device in the 
Information Society scene. Instead of only allowing access to technology, minorities and special social groups can be provided with this articulation-based UA articulation perspective, which can lead to social, financial, technological, and individual educational inclusion due to the results of technology [10].

One way to expand UA and increase the level of accessibility of interactive products and services is by developing Assistive Technologies (AT) and devices [11]. According to the World Health Organization, AT can consist of a device whose primary purpose is to maintain or increase individual independence to facilitate social participation and to improve overall well-being. AT can also help prevent secondary health conditions and disorders, such as the use of canes can also help people with mobility problems to avoid developing musculoskeletal problems. Examples of assistive devices and technology include wheelchairs, hearing aids, visual aids and special computers that increase mobility, hearing vision, or communication capacity.

First, the Medical Approach focuses on disorders and describes disability as a result of a health condition, illness or trauma that can interfere with the functioning of a person physiologically or cognitively. Disability is here understood as intrinsic to the individual who experiences it. In this approach, the disorder is a dysfunction that has the effect of excluding people with disabilities from critical social roles and obligations, making them dependent on family and community members [12]. Besides, these disorders or differences must be corrected, cured or changed with medical and other treatments, even when the disorder or difference does not cause pain or illness. The Medical Approach seeks what is wrong with the person, not what the person needs, which justifies medical action and rehabilitation answers. As a result, it creates low expectations and direction for people who lose independence and control over their own lives ([13]; [14]). [14] observe that this approach was the dominant model for understanding disability until the last few decades of the 20th century, and remains dominant in the famous assertion of disability.

Second, in the Functional Approach, a disability is identified not in terms of a previous medical condition, but by considering the functional limitations caused by impairment. Since this medical condition has no impact on a person's functional activities, there are no disabilities. Circumstances that limit an individual's ability to access transportation or work functions, this functional limitation causes disability. Functional limitations are related to the person's ability to engage in precisely key social roles, such as work or caring for family members ([13]; [14]).

Finally, under the Social Approach, a person with impaired mobility is not prevented from fully participating in society by impairment, but by the failure of policymakers, planners and builders to account for the presence of persons with impaired mobility and to make accessible transportation, buildings and services. According to the Social Approach, people with disabilities are not excluded from work so much by their medical condition as by fear, myths and lack of information that lead potential employers to turn a blind eye to their application [14]. From this perspective, disability is less an individual problem than a social problem; a person's activities are not limited by disturbances or conditions but by the environment and barriers which are a consequence of a lack of social organization [15].

The Social Approach states that it is the environment, and how the environment interacts with people, which must be improved and enhanced to provide quality of life and reduce exclusion. This perspective has had a profound impact on the flaws of public policy and theory over the past thirty years and is now the dominant approach among researchers and activists [13].

\section{RESEARCH METHOD}

This type of research used in this study is a qualitative descriptive research method. The data collection technique used by researchers is by using a combined pattern and then combined with the inductive data analysis process. This researcher conducts research that describes events or problems in the field, namely the accessibility of SIM services for people with disabilities in Bantul Police, especially in the field of SIM services.

\section{RESULT AND DISCUSSION}

\subsection{Tangible}

Facilities for priority and persons with disabilities at the Bantul Police, especially in the SIM service room, must be explicitly provided for persons with disabilities so that they do not have difficulties when making a SIM. Seats are provided by local authorities or SIM service officers who are already available, and there are special lanes for people with disabilities to make it easier for them to access special SIM services for persons with disabilities.

Some of the outstanding facilities available at the Bantul Police, especially in the SIM service unit specifically for persons with disabilities are the most important things that must be prioritized for the comfort of people with particular limitations. 
Table 1 Special Facilities for Persons with Disabilities

\begin{tabular}{|c|c|c|}
\hline No & $\begin{array}{c}\text { Special Facilities for Persons with } \\
\text { Disabilities }\end{array}$ & Jumlah \\
\hline 1 & Wheelchair & 3 \\
\hline 2 & Special / Priority Seat & 10 \\
\hline 3 & Special Counter & 1 \\
\hline
\end{tabular}

The special facilities at the Bantul Police are the most important things that need to be paid attention because the availability of adequate and comfortable special facilities will be very happy for visitors who have special needs with disabilities who will make a SIM. With the special room provided for persons with disabilities or people with special needs, it will be effortless when accessing SIM services at the Bantul Police.

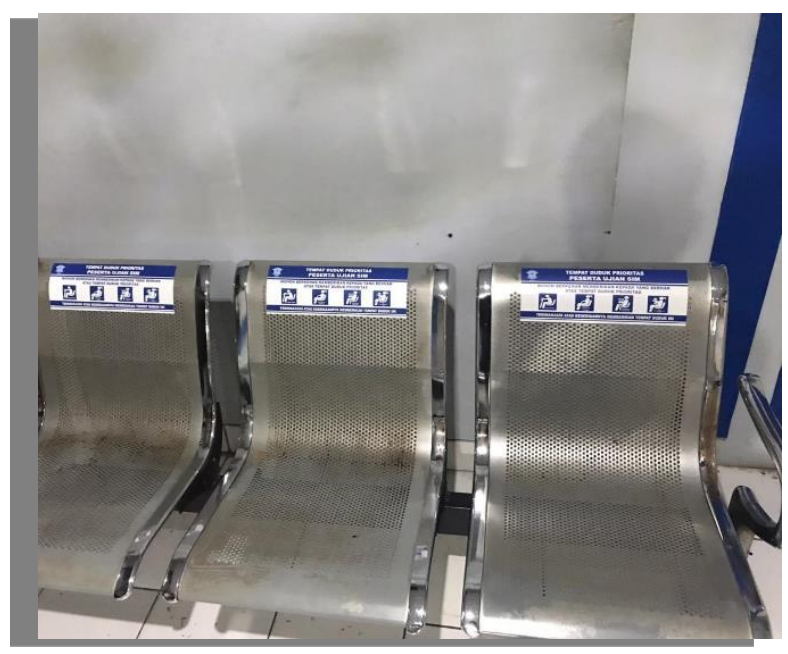

Figure 2 Priority dedicated seats

Referring to the picture above, the facilities available in the waiting room for SIM services are adequate, and special rooms are available, special seats and special counters for people with disabilities. The convenience of visitors with special needs.

\subsection{Reliability}

Reliability is the ability of a company or service provider to provide appropriate services promised with accuracy and certainty of time. The performance given must be following the wishes of the customer as required by each customer where the SIM service provider must provide more service and attention gently and understandably for people who have special needs or people with disabilities.

The organizers of the SIM making at the Bantul Police prioritize people in terms of special routes and roads for people with disabilities, because people with disabilities and non-disabled people have a different time from movement and things that may become limitations in carrying out the procedure for making a SIM. People with disabilities are prioritized and designated for special counters or rooms so that they do not interfere with other people. Still, the procedure remains the same in general, for the operational hours of the Bantul Police SIM service is opened at 08:00 to 15:00, but for services for persons with disabilities who do SIM service in terms of time was not enough, so it was extended until 16:00 WIB.

\subsection{Responsiveness}

Responsiveness is the ability of a person to perform services or service providers who provide services to consumers quickly and precisely. So that customers can understand what the service provider provides when conveying the information needed. However, Bantul Police, especially SIM operators, have not provided special vehicles for disabilities, and it is the same for non-disabled public vehicles. Because according to the organizers of the motor vehicle test instructions, it is prioritized that it is better to carry each vehicle with the type of vehicle being driven. This suggestion is recommended because people have different skills in using motorized vehicles, some are accustomed to automatic vehicles, and some are accustomed to manual/coupling vehicles. Vehicles for disabilities are also better to bring their motorbikes according to the needs they are used and the types of modifications that have special limitations on the motorbikes of each disability.

Bantul Police do not provide motorized vehicles. However, drivers or participants who want to test their vehicles in the motorized vehicle field are advised to bring their vehicles according to their daily needs. Because bringing their vehicle can make it easier for participants when driving on the SIM exam track at the Bantul Police. Likewise, persons with disabilities must bring their respective vehicles following their modifications to the applicable regulations, so that they are comfortable driving and driving when on the SIM exam route. When the SIM exam process is eligible to pass, the participant will immediately get a SIM according to their needs. If the participant does not pass, he will be given the opportunity in the next exam For persons with disabilities when conducting field material exams fail, the officer will help to ease it following the procedures for making a valid driving license so that it does not make it difficult for persons with disabilities. It is also seen that if the error is a little, the officer will help to pass. If it is still fatal and not feasible driving, the officer will give directions and be advised to carry out future tests because for the sake of driving comfort and safety when travelling in traffic.

\subsection{Assurance}

The guarantee is an employee ability of a service that provides a sense of trusts such as security, certainty, convenience and excellent and polite communication to customers. Services with this guarantee can produce maximum results which serve with those who are served to make both of them comfortable. As for the guarantee 
of good service and training when responding to persons with disabilities who want to visit the Bantul Police to carry out the procedure for making a SIM.

This point is essential to take care of service to create excellent and sure service. The service attitude of the public apparatus states that two attitudes must be had for everyone who serves, namely being friendly and caring about the conditions of people with disabilities. The SIM service provider staff represented by Aipda Bowo Kuntoro said that officers who serve must be able to provide special services with the abilities they control. So that officers can explain some of the points needed by persons with disabilities who will make a SIM.

Friendliness of officers is a form of concern for services, especially for people with disabilities, by giving a greeting and a smile to be one of the essential keys in service attitude as an officer. Services also do not have to provide information or SIM services only, but some officers help pick up people from the special parking lot for the disabled route. Due to difficulties with wheelchairs, the SIM service officer helps to encourage and direct them to special rooms for persons with disabilities. There is a special route for disabilities that goes to the SIM service counter. Wheelchairs are available at the SIM staff and at the Bantul Police Station to help people with walking difficulties or who are elderly.

The attitude of the officers is the same as for others, regardless of disabilities and non-disabilities. The treatment of officers with a friendly and polite attitude will make the people served happy and comfortable when getting service. As a sense of tolerance, people with disabilities may take precedence over non-disabled people due to limited time and abilities.

\subsection{Emphaty}

Empathy is meant to give sincere, individualized attention to customers without being picky. Service providers are expected to provide understanding and knowledge about how the flow and procedure of making a SIM are excellent and correct so that it can be understood by persons with disabilities in particular.

The treatment of persons with disabilities and nondisabled people is indeed a problem in service. There is discrimination against persons with disabilities, and there are also those who get equal services. The treatment of persons with disabilities and non-disabled people must differentiate their priorities and limitations. For SIM services at the Bantul Police, the treatment between people with disabilities and non-disabled people is the same, there is no difference, but in terms of time and priority, persons with disabilities must prioritize so that they finish quickly and don't wait a long time.

With the existence of mutual tolerance, it will be better in the future by presenting people with special limitations first. SIM service officers provide the same directions as non-disabled people, but those who are more assisted are people with disabilities because they often find it difficult

\section{CONCLUSION}

Based on the results of the research and discussions, the following conclusions can be drawn:

1. Tangible strives to show that those with disabilities should be given priority in the construction of facilities and infrastructure. It can cause some disabled people to be denied seating, or have to join with non-disabled people on the floor. As this occurs, the passengers may get a little uncomfortable.

2. It allows quick and easy access to SIM services, and does not disrupt the network. We prioritize services for people with disabilities because of physical limitations, and their own limits in moving around. There are special lanes set up for people with disabilities to get to their SIM cards and are also assisted by police when it is difficult to use their wheelchair.

3. Responsiveness are a need for SIM services at the Bantul Police to be fast and responsive. If the local officer cannot or will not give directions, the officer will assist you. Also acts, such as the limitation or deficiencies in terms of implementation of a SIM for persons with disabilities. But some police officers lack understanding of people with disabilities, so their attitudes are not good and they are not open enough.

4. Assurance aims to communicate and trust and security in SIM services for people with disabilities. In terms of how much respect the officers have towards disabled people, there are some who are indifferent, but there are also some who are great in this regard. A couple of staff members are a little better trained, but not to the max, but provide a direction and service that is easy to understand.

5. Empathy aims to prioritize individuals with disabilities. In order to offer special SIM services, persons with disabilities and non-disabled people are not discriminated against. It doesn't matter whether you are disabled or not, for SIM services at the Bantul Police, they all go to the same places. Officers help people with disabilities until they are made SIMs.

\section{ACKNOWLEDGMENTS}

Thank you to Universitas Muhammadiyah Yogyakarta.

\section{AUTHORS' CONTRIBUTIONS}

Atik Septi Winarsih: Conducting research with the literature review stage, collecting data and analyzing the data that has been collected. The author also plays an active role in making journal article manuscripts starting from the background, literature review to narrating data. 
Dewi Sekar Kencono and Muhammad Iqbal: the author analyzes the data and elaborates the relevant theoretical literature. The author is also actively involved in the formulation of research problems and adds a variety of relevant literature to strengthen the analysis and findings in the article.

\section{REFERENCES}

[1] Fibrianto, A. S. (2020). Difa City Tour dan Transport: Sebagai Wadah Kreatif untuk Mewujudkan Kehidupan Masyarakat Difabel Sejahtera. Media Informasi Penelitian Kesejahteraan Sosial, 42(1), 17-36.

[2] Tamba, J. (2017). A Juridical Study toward Indonesian Disabilities Right for Public Services Accessibility according to Law No. 8 Year 2016. IJDS: Indonesian Journal Of Disability Studies, 4(1), 63-68.

[3] Rahmat, D. A. (2019). Disparitas penerbitan Surat Izin Mengemudi sebagai pemenuhan hak bagi penyandang tunarungu. Jurnal Sosiologi Dialektika, 14(1), 26-33.

[4] Iqbal, M., \& Anggraini, A. T. 2019. Public Service Innovation For Public Transportation To Disabilities By Difa City Tour, Yogyakar City.

[5] Rahayu, U. D., \& Ahdiyana, M. (2013). Pelayanan Publik Bidang Transportasi bagi Difabel di Daerah Istimewa Yogyakarta. SOCIA: Jurnal Ilmu-Ilmu Sosial, 10(2).

[6] Wiratama, S. M. (2018). Pemenuhan Hak Penyandang Disabilitas Dalam Pelayanan Pembuatan Surat Izin Mengemudi (SIM) Di Kepolisian Resort Magetan

[7] Rahman, A. B. D., \& Ambrie, M. (2020). Pelayanan Pembuatan Surat Izin Mengemudi Bagi Masyarakat Berkebutuhan Khusus Di Kepolisian Resor Kota Banjarmasin. Jurnal PubBis, 4(1), 3952.

[8] Kuncoro, B. A., Widayati, W., \& Manar, D. G. (2014). Evaluasi Proses Perolehan Surat Ijin Mengemudi (Sim D) Bagi Penyandang Cacat Di Kabupaten Sidoarjo.Journal of Politics and Government Studies, 3(2), 76-85

[9] Dunlop, M. D., Roper, M., Elliot, M., McCartan, R., \& McGregor, B. (2016). Using smartphones in cities to crowdsource dangerous road sections and give effective in-car warnings. In Proceedings of the SEACHI 2016 on Smart Cities for Better Living with HCI and $U X$ (pp. 14-18).

[10] Puzin, S. N., Memetov, S. S., Shurgaya, M. A., \& Baleka, L. Y. (2016). Features of the organization of public service of medical and social expertise at the present stage. Medical and Social Expert Evaluation and Rehabilitation, 19(3), 159-163.

[11] Bezyak, J. L., Sabella, S. A., \& Gattis, R. H. (2017). Public transportation: an investigation of barriers for people with disabilities. Journal of Disability Policy Studies, 28(1), 52-60.

[12] Yanxia, Z. (2016). Social Security and Public Services for People with Disabilities in the Western Region of China_A Case Study in Buyi and Miao Autonomous Prefecture of Qianxinan, Guizhou Province. China Agricultural University Journal of Social Sciences Edition, (3), 11.

[13] Brandt Jr, E. N., \& Pope, A. M. (1997). Models of disability and rehabilitation. In Enabling America: Assessing the role of rehabilitation science and engineering. National Academies Press (US).

[14] Hersh, M., \& Johnson, M. A. (Eds.). (2010). Assistive technology for visually impaired and blind people. Springer Science \& Business Media.

[15] Majola, B. K., \& Dhunpath, R. (2016). The development of disability-related employment policies in the South African public service. Problems and perspectives in management, (14, Iss. 1 (contin)), 150-159.

[16] Jones, A. M., Finkelstein, R., \& Koehoorn, M. (2018). Disability and workplace harassment and discrimination among Canadian federal public service employees. Canadian Journal of Public Health, 109(1), 79-88

[17] Benyon, K., Muller, S., Hill, S., \& Mallen, C. (2013). Coping strategies as predictors of pain and disability in older people in primary care: a longitudinal study. BMC family practice, 14(1), 67.

[18] Pavlencu, M. (2019). Access for people with disabilities to public goods and services. In The contemporary issues of the socio-humanistic sciences (Vol. 10, pp. 78-79).

[19] Desectasari, D. P., \& Ristianti, N. S. (2019). Inclusive Public Service Space For Elderly With Disabilities Balance In Poncol Station District Semarang. Jurnal Teknik Sipil dan Perencanaan, 21(2), 81-89. 